\title{
A "miracle" cancer drug in the era of social media: A survey of Brazilian oncologists' opinions and experience with phosphoethanolamine
}

\author{
Juliana Florinda M. Rêgo ${ }^{1,2 *}$, Gilberto Lopes ${ }^{1,3}$, Rachel P. Riechelmann ${ }^{1,4,5}$, Cinthya Sternberg ${ }^{1,6}$, \\ Claudio Ferrari ${ }^{1,4}$, Gustavo Fernandes ${ }^{1,4}$ \\ ${ }^{1}$ Sociedade Brasileira de Oncologia Clínica, Natal, RN, Brazil \\ ${ }^{2}$ Universidade Federal do Rio Grande do Norte, Natal, RN, Brazil \\ ${ }^{3}$ Oncoclínicas do Brasil, São Paulo, SP, Brazil \\ ${ }^{4}$ Hospital Sírio-Libanês, São Paulo, SP, Brazil \\ Instituto do Câncer do Estado de São Paulo, São Paulo, SP, Brazil \\ ${ }^{6}$ Universidade Federal do Rio de Janeiro, Rio de Janeiro, RJ, Brazil
}

Study conducted by Sociedade Brasileira de Oncologia Clínica (SBOC), Brazil

Article received: 5/12/2016 Accepted for publication: 5/19/2016

*Correspondence: Address: Av. Nilo Peçanha, 620 Natal, RN - Brazil Postal code: $59012-300$ juliana.oncologia@gmail.com juli_florinda@hotmail.com

http://dx.doi.org/10.1590/1806-9282.63.01.70

\section{SUMmARY}

Introduction: Patients who are treating cancer have often used alternative therapies. In the internet era, information can be broadcasted widely, and this happened with phosphoethanolamine in Brazil, where this substance was claimed by the population to be the "cure for cancer."

Method: This is a cross-sectional study developed by the Brazilian Society of Clinical Oncology (SBOC). An objectively structured questionnaire was sent by e-mail and SMS to active MDs members of the SBOC. Descriptive statistics was used to evaluate the data. Statistical significance between the variables was tested by Pearson's Chi-squared test ( $\mathrm{p}<0.05$ was considered significance).

Results: The survey was sent to 1,072 oncologists, and 398 (37.1\%) answered at least part of it. One hundred and fifteen (28.9\%) had followed patients who had used phosphoethanolamine. Among these, 14 (12.2\%) observed adverse events and four $(3.5 \%)$ attributed clinical benefit to the substance. Most of the oncologists $(n=331 ; 83.2 \%)$ believe that it should only be used as part of a clinical trial protocol. Most physicians did not recommend this drug to their patients $(n=311$; 78.1\%). Oncologists in Southeast, South and Midwest Brazil were more likely to have patients taking the drug compared to the Northern and Northeastern regions. Conclusion: This is the first survey to assess the opinion and experience of oncologists about this alternative therapy. Most oncologists in Brazil do not believe that synthetic phosphoethanolamine is active in cancer treatment, do not recommend its use without proper evaluation, and state that it should only be available to patients in the context of clinical trials.

Keywords: phosphoethanolamine, alternative therapies, cancer, Brazil.

\section{INTRODUCTION}

Roughly 14.1 million new cases of cancer and 8.2 million deaths occurred worldwide in $2012 .{ }^{1}$ New drugs and treatments have started to improve outcomes in high-income nations as well as in low- and middle-income countries. Many alternative therapies, some even called "miracle therapies," have risen in every part of the world and a few cancer hoaxes exist that are older than the discipline of medical oncology itself. However, rarely we have had the opportunity to observe and document the appearance and development of an alternative treatment in real time as we now do for phosphoethanolamine in Brazil.

As social media has become more widely available, unreliable and untruthful information can be broadcasted to an even wider audience. In Brazil, it was social media that made a case for phosphoethanolamine and took the country by storm. Phosphoethanolamine is a precursor of the biosynthesis of phospholipids in the 
cellular membrane and part of the cell signaling system either directly or via second messengers. A chemistry professor and his team in one of the campuses of the University of São Paulo have studied the drug in its synthetic version. Potential antineoplastic effects have been demonstrated in a few preclinical studies using cell lines ${ }^{2-5}$ and mice models; $;{ }^{6,7}$ nonetheless, no appropriate safety studies have been carried out in humans. That has not kept the research team from manufacturing the substance in one of the chemistry laboratories at the university and distributing it to an increasing number of patients over the years. In 2015, after the university administration stopped this unsupported practice, patients who had been receiving the substance filed for court order to guarantee continued access to it.

In October 2015, one of the cases reached a Brazilian Federal Court judge, who ruled that patients could continue using phosphoethanolamine and that the university laboratory should not stop making it. Following this decision, additional lawsuits were brought forward. In the same month, a hearing in the National Congress demonstrated the commotion of patients who placed all their hope in the supposed drug and clamored for action. After this meeting, the Ministry of Health created and funded (to the tune of US $\$ 2.5$ million) a task force to conduct preclinical studies and clinical trials to evaluate phosphoethanolamine as a cancer treatment.

The upheaval and pressure from groups of patients and family members have been so forceful and misguided that legislators have approved a path for the distribution of phosphoethanolamine even before adequate studies were done and evaluated by the Brazilian drug authority, Anvisa (Agência Nacional de Vigilância Sanitária, in portuguese), which in conjunction with the Ministry of Health and medical groups are now asking the president to veto the bill.

As there are no clinical data available on the use of phosphoethanolamine, we designed this survey of medical oncologists in Brazil not only to evaluate their experience with the substance, but also to assess their knowledge, opinion and attitudes on this unfolding story.

\section{Method}

Study design

This was an official study designed and carried out by the Brazilian Society of Clinical Oncology (SBOC). We designed a cross-sectional study and developed a survey, which was sent three times by e-mail and three times by text message in 3 to 5-day intervals to active MDs member of the SBOC. A questionnaire with closed-ended questions was applied. The main issues were: how many patients used phosphoethanolamine, how many wished to use it, if any side effects or benefits were seen in those who used it, what was the oncologist's opinion and what recommendation was given to the patient regarding phosphoethanolamine, how many studies the doctor had access to, what would be their position in relation to the distribution of phosphoethanolamine, what was their opinion on the conduct of clinical studies, and the degree of agreement with the opinion of the representatives of SBOC. Data collected between December $11^{\text {th }}$ and $18^{\text {th }}, 2015$, included demographic information and the physicians' knowledge and opinions regarding the use of phosphoethanolamine in cancer treatment.

\section{Statistical analysis}

We used descriptive statistics to evaluate and present the data gathered.

Contingency tables were used to associate the sample characteristics (region where respondent practices, gender and field of practice) to the provided answers regarding phosphoethanolamine. Statistical significance between the variables was tested by Pearson's Chi-squared test.

Data was processed using statistical software PASW, version 18. In all statistical tests, a two-tailed level of 5\% of significance $(\mathrm{p}<0.05)$ was considered.

A formal sample size computation was not performed because this was an exploratory cross-sectional study where the more responses we had, the more information we would gather about the physicians' experience with phosphoethanolamine. Therefore, we aimed to gather the maximum respondents among all current 1,072 active members of the SBOC.

\section{Results}

\section{Characteristics of the respondents}

The survey was sent to all oncologists who were active members of the SBOC (1,072 doctors), of which 398 (37.1\%) answered at least part of it. Among responders, 209 (52.5\%) practice medicine in the Southeastern region, 67 (16.8\%) in the Northeastern region, $71(17.8 \%)$ in the Southern region, $34(8.5 \%)$ in the Midwestern region and eight (2\%) in the Northern region (Figure 1). Nine doctors (2.3\%) did not answer which region they were from. 104 (26.1\%) of the individuals were men and $49(12.3 \%)$ were women (61.6\% of respondents did not answer this question).

As for the setting of practice, 170 (42.7\%) oncologists perform their activities in both the public and private sectors, 163 (41\%) work predominantly in the private sector and $64(16.1 \%)$ predominantly in the public sector. 


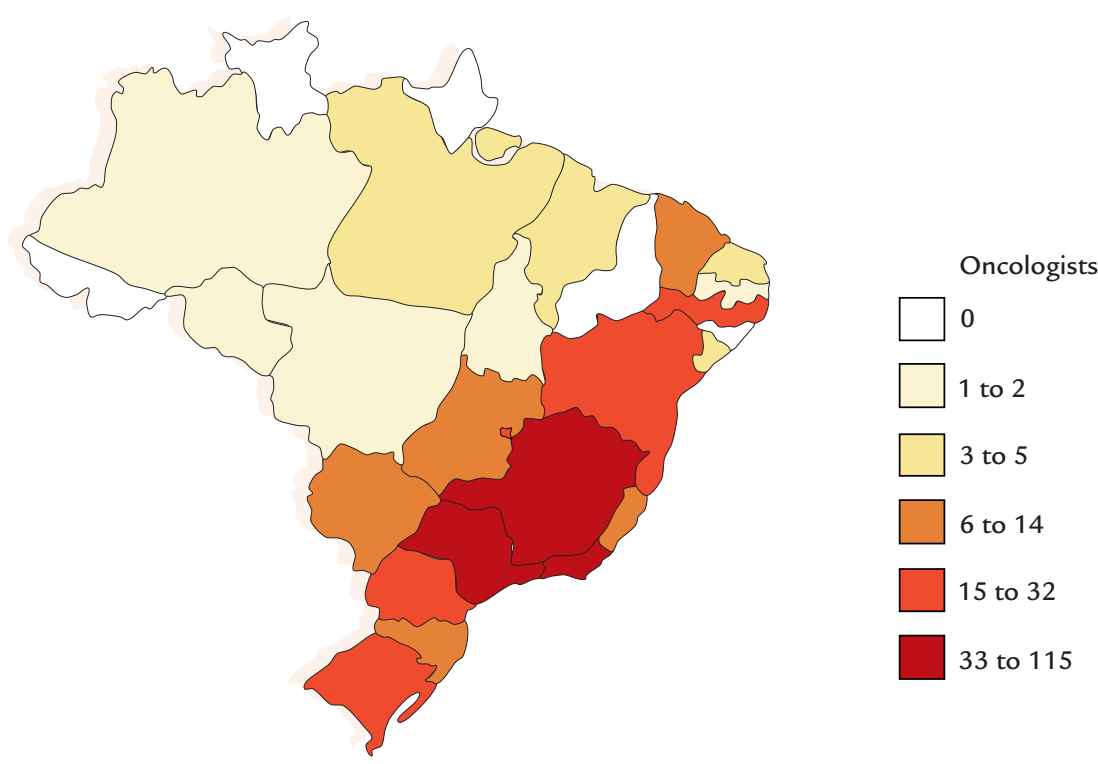

FIGURE 1 Distribution of oncologists by state who answered the survey.

One hundred and fifteen (28.9\%) oncologists had followed patients who had used or were using phosphoethanolamine, 93 of whom (80.9\%) had up to five patients in this scenario. Among them, only 14 (12.2\%) physicians observed any adverse events and four (3.5\%) attributed some clinical benefit to the treatment. A total of 378 (95\%) respondents stated that they had had patients who wished to use this substance.

As for the recommendation given to patients about the use of phosphoethanolamine, 198 (49.7\%) oncologists did not recommend its use, 113 (28.4\%) contraindicated it, $42(10.6 \%)$ accepted its use as a complementary treatment as long as another prescribed treatment with an approved drug was maintained, and 15 (3.8\%) accepted it depending on the circumstances.

Overall, 299 (75.1\%) respondents had not read any scientific studies on phosphoethanolamine, 94 (23.6\%) had read between one and five preclinical studies, four $(1 \%)$ had read five to ten, and one $(0.3 \%)$ individual answered that he or she had read more than ten studies.

One hundred and fifty four oncologists (38.7\%) did not have any informed opinion regarding the drug, and of these, 112 (72.7\%) thought it was likely to be well-tolerated. About a quarter of respondents (96, 24.1\%) were not convinced of its efficacy despite considering that phosphoethanolamine is likely to be well-tolerated, 31 (7.8\%) believed it to be not active and likely to have relevant adverse effects, and two $(0.5 \%)$ considered it as likely to be an active drug.
As for patient access to phosphoethanolamine, 331 oncologists (83.2\%) defended the position that it should only be provided to patients in the context of clinical trials, 26 (6.5\%) that it could be considered off protocol, since there were no potentially approved treatments, and two $(0.5 \%)$ said that it should be administered to any patient who asks for it. The others had either no informed opinion or did not answer.

When questioned if clinical trials probing phosphoethanolamine were a priority, $113(28.4 \%)$ of the respondents agreed, whereas 197 (49.5\%) shared the opinion that testing is necessary but not a priority. Approximately two thirds of oncologists ( $n=267 ; 67.1 \%$ ) completely agreed with the position of the SBOC representatives in their public opinions, whereas 36 (6\%) partly agreed. However, 86 oncologists $(21.6 \%)$ had not seen the interviews nor read the articles in which the society stated its views that adequate clinical trials and evaluation by Anvisa should be undertaken before the substance becomes available to the public.

These results are detailed in Tables 1,2 and 3.

\section{Chi-square tests}

No significant associations were observed between site of practice (private and/or public sector) and any of the answers to the survey.

There was a significant association between region and access to phosphoethanolamine. Oncologists in the Southeast, South, and Midwest were more likely to have patients 
TABLE 1 Medical oncologists' experience with phosphoethanolamine.

Questions about phosphoethanolamine

Region where the respondents reside

p-value

\begin{tabular}{|c|c|c|c|c|c|c|c|c|c|c|c|}
\hline & \multirow{3}{*}{$\begin{array}{l}\text { Brazil } \\
N^{*}\end{array}$} & \multirow{2}{*}{\multicolumn{2}{|c|}{ North-Northeast }} & \multirow{2}{*}{\multicolumn{2}{|c|}{ Midwest }} & \multirow{2}{*}{\multicolumn{2}{|c|}{ Southeast }} & \multirow{2}{*}{\multicolumn{2}{|c|}{ South }} & \\
\hline & & & & & & & & & & & \\
\hline & & & $\mathbf{n}$ & $\%$ & $\mathbf{n}$ & $\%$ & $\mathbf{n}$ & $\%$ & $\mathbf{n}$ & $\%$ & \\
\hline \multirow{4}{*}{$\begin{array}{l}\text { How many patients under } \\
\text { your care used or are } \\
\text { using } \\
\text { phosphoethanolamine? }\end{array}$} & None & 276 & 61 & 81.3 & 20 & 58.8 & 146 & 69.9 & 49 & 69.0 & $.018 *$ \\
\hline & 1 to 5 patients & 92 & 14 & 18.7 & 12 & 35.3 & 52 & 24.9 & 14 & 19.7 & \\
\hline & 5 to 10 patients & 13 & 0 & 0 & 2 & 5.9 & 8 & 3.8 & 3 & 4.2 & \\
\hline & More than 10 patients & 8 & 0 & 0 & 0 & 0 & 3 & 1.4 & 5 & 7.0 & \\
\hline \multirow{4}{*}{$\begin{array}{l}\text { How many patients under } \\
\text { your care expressed the } \\
\text { desire of using } \\
\text { phosphoethanolamine? }\end{array}$} & None & 19 & 1 & 1.3 & 0 & 0 & 12 & 5.7 & 6 & 8.5 & .195 \\
\hline & 1 to 5 patients & 116 & 26 & 34.7 & 9 & 26.5 & 63 & 30.1 & 18 & 25.4 & \\
\hline & 5 to 10 patients & 73 & 20 & 26.7 & 7 & 20.6 & 35 & 16.7 & 11 & 15.5 & \\
\hline & More than 10 patients & 181 & 28 & 37.3 & 18 & 52.9 & 99 & 47.4 & 36 & 50.7 & \\
\hline \multirow{5}{*}{$\begin{array}{l}\text { In the follow-ups, did you } \\
\text { observe any adverse effect } \\
\text { that you attributed to } \\
\text { phosphoethanolamine? }\end{array}$} & No & 95 & 10 & 13.3 & 10 & 29.4 & 50 & 23.9 & 15 & 21.7 & .344 \\
\hline & I did not follow & 288 & 63 & 84.0 & 24 & 70.6 & 150 & 71.8 & 51 & 73.9 & \\
\hline & patients with & & & & & & & & & & \\
\hline & phosphoethanolamine & & & & & & & & & & \\
\hline & Yes & 14 & 2 & 2.7 & 0 & 0 & 9 & 4.3 & 3 & 4.3 & \\
\hline \multirow{5}{*}{$\begin{array}{l}\text { Did you consider any } \\
\text { benefit that you } \\
\text { attributed to the } \\
\text { treatment? }\end{array}$} & No & 98 & 12 & 16.0 & 9 & 26.5 & 56 & 26.8 & 21 & 30.4 & .421 \\
\hline & I did not follow & 285 & 62 & 82.7 & 25 & 73.5 & 150 & 71.8 & 48 & 69.6 & \\
\hline & patients with & & & & & & & & & & \\
\hline & phosphoethanolamine & & & & & & & & & & \\
\hline & Yes & 4 & 1 & 1.3 & 0 & 0 & 3 & 1.4 & 0 & 0 & \\
\hline \multirow{9}{*}{$\begin{array}{l}\text { How do you advise your } \\
\text { patients who are using or } \\
\text { wish to use } \\
\text { phosphoethanolamine? }\end{array}$} & I accept the use as long & & 3 & 4.0 & 7 & 20.6 & 22 & 10.5 & 8 & 11.3 & .138 \\
\hline & as they do not abandon & 40 & & & & & & & & & \\
\hline & the prescribed & & & & & & & & & & \\
\hline & treatment & & & & & & & & & & \\
\hline & $\begin{array}{l}\text { I contraindicate it } \\
\text { emphatically }\end{array}$ & 111 & 23 & 30.7 & 9 & 26.5 & 59 & 28.2 & 20 & 28.2 & \\
\hline & $\begin{array}{l}\text { Depending on the } \\
\text { situation, I support } \\
\text { its use }\end{array}$ & 15 & 2 & 2.7 & 1 & 2.9 & 10 & 4.8 & 2 & 2.8 & \\
\hline & $\begin{array}{l}\text { I do not discuss the } \\
\text { matter }\end{array}$ & 7 & 1 & 1.3 & 0 & 0 & 6 & 2.9 & 0 & 0 & \\
\hline & None of the above & 22 & 0 & 0 & 2 & 5.9 & 17 & 8.1 & 3 & 4.2 & \\
\hline & $\begin{array}{l}\text { I recommend that they } \\
\text { do not use it }\end{array}$ & 194 & 46 & 61.3 & 15 & 44.1 & 95 & 45.5 & 38 & 53.5 & \\
\hline \multirow{4}{*}{$\begin{array}{l}\text { How many studies about } \\
\text { phosphoethanolamine } \\
\text { have you read? }\end{array}$} & None & 290 & 63 & 84.0 & 26 & 76.5 & 151 & 72.2 & 50 & 70.4 & .696 \\
\hline & 1 to 5 studies & 94 & 12 & 16.0 & 8 & 23.5 & 54 & 25.8 & 20 & 28.2 & \\
\hline & 5 to 10 studies & 4 & 0 & 0 & 0 & 0 & 3 & 1.4 & 1 & 1.4 & \\
\hline & More than 10 studies & 1 & 0 & 0 & 0 & 0 & 1 & .5 & 0 & .0 & \\
\hline Total & & 389 & 75 & 100.0 & 34 & 100.0 & 209 & 100.0 & 71 & 100.0 & \\
\hline
\end{tabular}

Note: The statistical significance ( $\mathrm{p}$-value) refers to Chi-Square test.

* Nine doctors (2.3\%) did not answer these questions. 
TABLE 2 Medical oncologists' opinions on phosphoethanolamine.

Questions about phosphoethanolamine

Region where the respondents reside

p-value

\begin{tabular}{|c|c|c|c|c|c|c|c|c|c|c|c|}
\hline & \multirow{2}{*}{$\begin{array}{l}\text { Brazil } \\
\mathrm{N}^{*}\end{array}$} & \multicolumn{2}{|c|}{ North-Northeast } & \multicolumn{2}{|c|}{ Midwest } & \multicolumn{2}{|c|}{ Southeast } & \multicolumn{2}{|c|}{ South } & \\
\hline & & & $\mathbf{n}$ & $\%$ & $\mathbf{n}$ & $\%$ & $\mathbf{n}$ & $\%$ & $\mathbf{n}$ & $\%$ & \\
\hline \multirow{17}{*}{$\begin{array}{l}\text { What is your opinion } \\
\text { about phosphoetha- } \\
\text { nolamine? }\end{array}$} & I believe that it is not & 30 & 6 & 8.0 & 1 & 2.9 & 16 & 7.8 & 7 & 9.9 & .835 \\
\hline & active and that it causes & & & & & & & & & & \\
\hline & significant adverse events & & & & & & & & & & \\
\hline & I believe that it is not & 109 & 18 & 24.0 & 15 & 44.1 & 55 & 26.7 & 21 & 29.6 & \\
\hline & active, but believe it is & & & & & & & & & & \\
\hline & likely to be well-tolerated & & & & & & & & & & \\
\hline & I am convinced of its & 1 & 0 & 0 & 0 & 0 & 1 & .5 & 0 & 0 & \\
\hline & efficacy and that it is & & & & & & & & & & \\
\hline & well-tolerated & & & & & & & & & & \\
\hline & I am convinced of its & 1 & 0 & 0 & 0 & 0 & 1 & .5 & 0 & 0 & \\
\hline & efficacy but I have doubts & & & & & & & & & & \\
\hline & about its tolerability & & & & & & & & & & \\
\hline & I am not convinced of its & 95 & 20 & 26.7 & 5 & 14.7 & 50 & 24.3 & 20 & 28.2 & \\
\hline & efficacy but I believe it to & & & & & & & & & & \\
\hline & be well-tolerated & & & & & & & & & & \\
\hline & I have no opinion about & 150 & 31 & 41.3 & 13 & 38.2 & 83 & 40.3 & 23 & 32.4 & \\
\hline & phosphoethanolamine & & & & & & & & & & \\
\hline \multirow{12}{*}{$\begin{array}{l}\text { What is your position } \\
\text { regarding the } \\
\text { distribution of } \\
\text { phosphoethanolamine } \\
\text { to patients with } \\
\text { cancer? }\end{array}$} & I do not have enough & 35 & 6 & 8.1 & 2 & 5.9 & 22 & 10.5 & 5 & 7.1 & .065 \\
\hline & information to have & & & & & & & & & & \\
\hline & an opinion & & & & & & & & & & \\
\hline & It can be considered for & 26 & 3 & 4.1 & 5 & 14.7 & 17 & 8.1 & 1 & 1.4 & \\
\hline & patients with no & & & & & & & & & & \\
\hline & alternative approved & & & & & & & & & & \\
\hline & treatment, even outside & & & & & & & & & & \\
\hline & clinical trials & & & & & & & & & & \\
\hline & It can be considered for & 2 & 0 & 0 & 1 & 2.9 & 0 & 0 & 1 & 1.4 & \\
\hline & any patient & & & & & & & & & & \\
\hline & It should only be provided & 324 & 65 & 87.8 & 26 & 76.5 & 170 & 81.3 & 63 & 90.0 & \\
\hline & to patients in clinical trials & & & & & & & & & & \\
\hline Total & & 387 & 75 & 100.0 & 34 & 100.0 & 209 & 100.0 & 71 & 100.0 & \\
\hline
\end{tabular}

Note: The statistical significance ( $p$-value) refers to Chi-Square test.

*Eleven doctors $(2.3 \%)$ did not answer these questions. 
TABLE 3 Medical oncologists' attitudes towards clinical trials of phosphoethanolamine and the Brazilian Society of Clinical Oncology statements and position.

Questions about phosphoethanolamine

Region where the respondents reside

p-value

\begin{tabular}{|c|c|c|c|c|c|c|c|c|c|c|c|}
\hline & & \multirow{2}{*}{$\begin{array}{l}\text { Brazil } \\
\mathrm{N}^{*}\end{array}$} & \multicolumn{2}{|c|}{ North-Northeast } & \multicolumn{2}{|c|}{ Midwest } & \multicolumn{2}{|c|}{ Southeast } & \multicolumn{2}{|c|}{ South } & \\
\hline & & & $\mathbf{n}$ & $\%$ & $\mathbf{n}$ & $\%$ & $\mathbf{n}$ & $\%$ & $\mathbf{n}$ & $\%$ & \\
\hline \multirow{18}{*}{$\begin{array}{l}\text { What is your opinion } \\
\text { about carrying out } \\
\text { clinical trials on } \\
\text { phosphoethanolamine? }\end{array}$} & I think they are & 4 & 3 & 4.0 & 0 & 0 & 1 & .5 & 0 & 49.3 & \multirow[t]{18}{*}{0.093} \\
\hline & unnecessary as I am & & & & & & & & & & \\
\hline & convinced that the & & & & & & & & & & \\
\hline & substance has no activity & & & & & & & & & & \\
\hline & I think they are & 195 & 38 & 50.7 & 20 & 58.8 & 102 & 49.0 & 35 & 5.6 & \\
\hline & necessary but should & & & & & & & & & & \\
\hline & not be a priority & & & & & & & & & & \\
\hline & I do not have enough & 34 & 11 & 14.7 & 3 & 8.8 & 16 & 7.7 & 4 & 12.7 & \\
\hline & information to have & & & & & & & & & & \\
\hline & an opinion & & & & & & & & & & \\
\hline & I am against it, as I & 46 & 4 & 5.3 & 2 & 5.9 & 31 & 14.9 & 9 & 32.4 & \\
\hline & believe that preclinical & & & & & & & & & & \\
\hline & trial data are & & & & & & & & & & \\
\hline & insufficient to bring it & & & & & & & & & & \\
\hline & for clinical studies & & & & & & & & & & \\
\hline & Clinical trials are & 109 & 19 & 25.3 & 9 & 26.5 & 58 & 27.9 & 23 & 0 & \\
\hline & necessary and should & & & & & & & & & & \\
\hline & be considered a priority & & & & & & & & & & \\
\hline \multirow{6}{*}{$\begin{array}{l}\text { How strongly do you } \\
\text { agree with the position } \\
\text { of SBOC } \\
\text { representatives in } \\
\text { regards to their public } \\
\text { display of opinions? }\end{array}$} & I partly agree & 35 & 4 & 5.3 & 6 & 17.6 & 17 & 8.2 & 8 & 11.3 & \multirow[t]{6}{*}{.204} \\
\hline & I completely agree & 265 & 55 & 73.3 & 22 & 64.7 & 139 & 66.8 & 49 & 69.0 & \\
\hline & I partly disagree & 6 & 0 & 0 & 0 & 0 & 3 & 1.4 & 3 & 4.2 & \\
\hline & I completely disagree & 2 & 1 & 1.3 & 0 & 0 & 0 & 0 & 1 & 1.4 & \\
\hline & I did not follow the & 80 & 15 & 20.0 & 6 & 17.6 & 49 & 23.6 & 10 & 14.1 & \\
\hline & interviews and articles & & & & & & & & & & \\
\hline \multirow{5}{*}{$\begin{array}{l}\text { Would you like to see } \\
\text { another position } \\
\text { defended by SBOC? }\end{array}$} & No & 226 & 45 & 60.8 & 23 & 67.6 & 116 & 56.0 & 42 & 60.0 & \multirow[t]{6}{*}{.570} \\
\hline & I did not follow the & 88 & 19 & 25.7 & 6 & 17.6 & 51 & 24.6 & 12 & 17.1 & \\
\hline & articles. I would rather & & & & & & & & & & \\
\hline & not comment & & & & & & & & & & \\
\hline & Yes & 71 & 10 & 13.5 & 5 & 14.7 & 40 & 19.3 & 16 & 22.9 & \\
\hline \multicolumn{2}{|l|}{ Total } & 385 & 75 & 100.0 & 34 & 100.0 & 209 & 100.0 & 71 & 100.0 & \\
\hline
\end{tabular}

Note: The statistical significance ( $\mathrm{p}$-value) refers to Chi-Square test.

*Thirteen doctors $(2.3 \%)$ did not answer these questions.

taking the substance compared with those in the North and Northeast.

\section{Discussion}

There is clearly a need for more active therapeutic alternatives in cancer treatment and patients who have no further specific anticancer options may easily fall prey to the use of unproven therapies, especially when unconfirmed and poorly documented cases of response or symptomatic improvement appear in social media. In Brazil, phospho- ethanolamine has quickly become the most commented-about alternative treatment.

In this study, we show that almost all oncologists in Brazil have had patients who voiced an interest in phosphoethanolamine and that a little less than one third of physicians in the country have treated individuals who used the substance. Potential clinical benefit, defined as clinical response or symptomatic improvement, was reported by a very small number of respondents (3.5\%), as was the incidence of adverse events (reported by only $12.2 \%$ of oncologists). 
The vast majority of oncologists do not think there is enough evidence for efficacy and do not recommend the drug, stating that it should be only used in the context of a clinical trial. Information about phosphoethanolamine is still very limited: $75 \%$ of the oncologists surveyed stated that they had never read any articles evaluating it and around one in five did not follow the interviews and mainstream media articles on the subject. This reflects the complete lack of scientific evidence about the clinical outcomes offered by phosphoethanolamine. The only available literature comprises preclinical studies with cell cultures and animal models where this substance has shown some antitumor activities in solid tumors, with the most recent one involving renal cell carcinoma. ${ }^{5}$

A significant difference in the number of oncologists who followed patients using phosphoethanolamine in different regions of the country was observed. This is likely to be due to access to the molecule, which is produced in São Paulo, in the Southeastern region of Brazil, therefore making it more accessible in this area and in the adjacent South and Midwest of Brazil.

It is clear from the short time of it took us to enroll the planned sample in this study (only one week) that there is strong interest within the medical community; congressional hearings and the approved bill creating a path for the distribution of phosphoethanolamine also attest to the public's interest in this matter. SBOC and its members strongly believe, however, that adequate clinical trials are of paramount importance and absolutely needed before the substance can be considered in the treatment of patients with cancer. Furthermore, the uncontrolled distribution and use of phosphoethanolamine without proper evidence of its benefits and safety constitute a hazard to public health in Brazil.

Cancer patients often take alternative compounds. Systematic reviews have reported that 40 to $90 \%$ of patients with breast or gynecology cancers have taken alternative medicines while on oncology treatments or follow-up. ${ }^{8}$ In this context, several supposedly "miracle drugs" such as herbs, vitamins, and fruit extracts, among others, have appeared in different countries. Commotion is expected within the society because cancer patients and their relatives are desperate to try anything that could cure or prolong their lives. Financial interests have led to many unproven compounds to be sold to cancer patients worldwide. One example is that of Sun Mushroom (Agaricus), which is native to Brazil and was used in the past for virtually all medical conditions, including cancer, due to its pre-clinical immunomodulatory effects. ${ }^{9}$ Despite not being formally tested in clinical trials, it was used off-label in Brazil by many cancer patients. While the clinical effects of this mushroom have never been published, adverse events were observed in some patients, such as severe hepatic dysfunction. This example stresses how crucial it is to formally test new compounds in well-designed clinical trials.

This study has some limitations, the main one being a possible selection bias. Only active members of the SBOC were invited to answer the survey and $37.1 \%$ of them answered the questionnaire. However, given that this is the first survey about the experience with phosphoethanolamine and there are no clinical trials available studying the use of this substance, it represents the best available evidence for its use. Detailed information about tumor types and setting were not collected, which prevented us from evaluating the cases of responsive patients.

We expect that society, lawmakers, and the judicial system will reach the understanding that drug development is a scientific matter and redirect their efforts into improving and expediting our regulatory system for clinical trials and drug approval, speeding up the availability of truly promising drug candidates and proven medications to our patients.

\section{Conclusion}

To our knowledge, this is the first survey to assess the opinion and experience of oncologists during the early stages of use of a supposed "miracle" alternative therapy. The results show that most oncologists in Brazil do not believe that synthetic phosphoethanolamine is active in the treatment of cancer, do not recommend its use without proper evaluation, and state that it should only be available to patients in the context of clinical trials.

\section{Resumo}

Uma "milagrosa” droga contra o câncer na era da mídia social: uma pesquisa sobre a opinião e a experiência dos oncologistas brasileiros com a fosfoetanolamina

Introdução: Alguns pacientes com diagnóstico de câncer utilizam terapias alternativas. Na era da internet, as informações podem se dissipar de forma rápida e abrangente, como foi o caso da fosfoetanolamina no Brasil, onde foi aclamada pela população como sendo a "cura para o câncer". Método: Trata-se de um estudo transversal desenvolvido pela Sociedade Brasileira de Oncologia Clínica (SBOC). Através de e-mail e SMS, enviou-se um questionário com perguntas objetivas para oncologistas membros ativos da SBOC. Os dados foram avaliados por meio de estatística descritiva. A significância estatística entre as variáveis foi 
testada pelo teste Qui-quadrado de Pearson ( $\mathrm{p}<0,05$ foi considerado significativo).

Resultados: O questionário foi enviado para 1.072 oncologistas, tendo $398(37,1 \%)$ respondido pelo menos parte dele. Cento e quinze $(28,9 \%)$ tinham pacientes que fizeram uso da fosfoetanolamina. Desses, 14 (12,2\%) observaram eventos adversos e quatro (3,5\%) atribuíram benefício clínico para a substância. A maioria ( $n=331 ; 83,2 \%)$ acreditava que ela só deveria ser utilizada dentro de um ensaio clínico. A principal recomendação dada aos pacientes foi contra o seu uso $(\mathrm{n}=311 ; 78,1 \%)$. Oncologistas das regiões Sudeste, Sul e Centro-Oeste tiveram mais pacientes que tomaram a substância quando comparados com as regiões Norte e Nordeste. Conclusão: Este é o primeiro estudo que avalia a opinião dos oncologistas sobre essa terapia alternativa e sua experiência. A maioria dos oncologistas brasileiros não acredita que a fosfoetanolamina sintética seja ativa no tratamento do câncer, não recomendando seu uso sem avaliação adequada, e afirmam que a substância só deve estar disponível no contexto de ensaios clínicos.

Palavras-chave: fosfoetanolamina, terapias alternativas, câncer, Brasil.

\section{REFEREnCES}

1. Torre LA, Bray F, Siegel RL, Ferlay J, Lortet-Tieulent J, Jemal A. Global cancer statistics, 2012. CA Cancer J Clin. 2015; 65(2):87-108.

2. Ferreira AK, Meneguelo R, Pereira A, Mendonça Filho O, Chierice GO, Maria DA. Anticancer effects of synthetic phosphoethanolamine on Ehrlich ascites tumor: an experimental study. Anticancer Res. 2012; 32(1):95-104.

3. Ferreira AK, Meneguelo R, Pereira A, Filho OM, Chierice GO, Maria DA Synthetic phosphoethanolamine induces cell cycle arrest and apoptosis in human breast cancer MCF-7 cells through the mitochondrial pathway. Biomed Pharmacother. 2013; 67(6):481-7.

4. Ferreira AK, Santana-Lemos BA, Rego EM, Filho OM, Chierice GO, Maria DA. Synthetic phosphoethanolamine has in vitro and in vivo anti-leukemia effects. Br J Cancer. 2013; 109(11):2819-28.

5. Ferreira AK, Freitas VM, Levy D, Ruiz JL, Bydlowski SP, Rici RE, et al. Antiangiogenic and anti-metastatic activity of synthetic phosphoethanolamine. PLoS One. 2013; 8(3):E57937.

6. Ferreira AK, Meneguelo R, Marques FL, Radin A, Filho OM, Neto SC, et al. Synthetic phosphoethanolamine a precursor of membrane phospholipids reduce tumor growth in mice bearing melanoma B16-F10 and in vitro induce apoptosis and arrest in $\mathrm{G} 2 / \mathrm{M}$ phase. Biomed Pharmacother. 2012; 66(7):541-8.

7. Fernandes GS, Lopes GL. More convoluted than a Brazilian soap opera: how an eager chemistry professor and a well-intended but misguided federal judge ignited an industry of false hopes. J Global Oncol. 2016; 2(1):167-8

8. Akpunar D, Bebis H, Yavan T. Use of complementary and alternative medicine in patients with gynecologic cancer: a systematic review. Asian Pac J Cancer Prev. 2015; 16(17):7847-52.

9. Hetland G, Johnson E, Lyberg T, Bernardshaw S, Tryggestad AM, Grinde B. Effects of the medicinal mushroom Agaricus blazei Murill on immunity, infection and cancer. Scand J Immunol. 2008; 68(4):363-70. 